\section{Occurrence, Severity and Initiation of Internal Necrosis in 'Covington' Sweetpotato}

\author{
Chen Jiang ${ }^{1}$, Penelope Perkins-Veazie ${ }^{1}$, Sylvia M. Blankenship ${ }^{1}$, \\ Michael D. Boyette ${ }^{2}$, Zvezdana Pesic-VanEsbroeck ${ }^{3}$, \\ Katherine M. Jennings ${ }^{1}$, and Jonathan R. Schultheis ${ }^{1,4}$
}

AdDitional Index wORDs. Ipomoea batatas, ethylene, ethephon, storage, curing, storage root

Summary. A series of studies were conducted to better understand the occurrence and causes of internal necrosis (IN) in 'Covington' sweetpotato (Ipomoea batatas). Assessment of the problem among the industry was done for 2 years and revealed that IN was widespread in commercial storage facilities throughout the state of North Carolina; both incidence and severity were generally low $(<10 \%$ incidence with minimal severity of symptoms). A few storage rooms had a high percentage of IN with severe storage root symptoms but results were inconsistent across years and among rooms. Preharvest studies with commercially used insecticides did not induce IN, but the harvest aid ethephon consistently induced IN with an incidence higher than $\mathbf{5 0 \%}$. Internal necrosis symptoms were not detectable at harvest, and earliest consistent incidence was observed 6 days after harvest (DAH) during the curing phase. Symptoms became more prevalent and severe at $30 \mathrm{DAH}$. However, in commercial storage rooms, no relationship was found between IN incidence and postcuring storage temperature or relative humidity $(\mathrm{RH})$ conditions. Sweetpotato storage roots stored in air-tight barrels and exposed to $100 \mathrm{ppm}$ ethylene after curing showed no relationship between the presence of ethylene gas in storage and incidence of IN. Our results indicate that IN incidence of 'Covington' is erratic with no obvious cause among storage rooms and that initiation of IN may occur most frequently during the first week following harvest.

$\mathrm{T}$ he sweetpotato cultivar, Covington, was released by the North Carolina State University Sweetpotato Breeding and Genetics Program (Yencho et al., 2008). North Carolina is the leading sweetpotato producer in the United States, with 63,000 acres planted in 2012 and comprises $47 \%$ of the national production (North Carolina Department

The assistance of Allan Thornton, Amie Newsome,
Billy Little, Bob Filbrun, Mike Wilder, Nicole San-
chez, Mark Abney, and Stephen Meyers is gratefully
acknowledged, and we thank the North Carolina
sweetpotato growers for their kind support and
participation in this project, and the North Carolina
Sweetpotato Commission and Specialty Crops Re-
search Initiative for their financial support.

Mention of a trademark, proprietary product, or vendor does not constitute a guarantee or warranty of the product by North Carolina State University and does not imply its approval to the exclusion of other products or vendors that also may be suitable.

${ }^{1}$ Department of Horticultural Science, North Carolina State University, Box 7609, 2721 Founders Drive, Raleigh, NC 27695

${ }^{2}$ Department of Biological \& Agricultural Engineering, North Carolina State University, Box 7625, D.S. Weaver Labs, Raleigh, NC 27695

${ }^{3}$ Department of Plant Pathology, North Carolina State University, 3709 Hillsborough Street, Raleigh, NC 27695

${ }^{4}$ Corresponding author. E-mail: jonathan_schultheis@ ncsu.edu. of Agriculture and Consumer Services, 2012). 'Covington' has excellent internal and external quality and is grown in over $80 \%$ of the commercial acreage across the state (S. JohnsonLangdon, personal communication). When added to the small amount of production of this cultivar in other states, nearly $40 \%$ of sweetpotato production across the United States consists of 'Covington'.

Internal necrosis in 'Covington' was first noted in Fall 2006 by a North Carolina grower. Once the incidence was discovered, 'Covington' storage root stocks from all of the Certified Seed Growers were evaluated in Feb.
2007. One farm, in which the original report of IN was made, had a high incidence of symptoms, some being severe. A few other farms had less than $2 \%$ incidence, whereas most farms had storage roots exhibiting no symptoms.

Internal necrosis symptoms are not evident on the exterior of storage roots, which precludes early detection of affected roots. Symptoms are visible as the cortex of the storage root is exposed through cutting. Symptoms usually start at the proximal end and progress toward the distal end, but rarely extend more than halfway down the length of the storage root. Necrosis symptoms vary from small (a few millimeters) black or brown spots to large areas $(3-5 \mathrm{~cm})$ of breakdown (Fig. 1).

Since the first discovery of IN, a number of reports and investigations have addressed the problem. One grower in 2009 reported that 1600 tons of sweetpotato in storage were affected by IN. Another grower reported that 'Covington' storage roots from the same harvest but placed in different storage rooms had no IN in one storage room, whereas roots in the other room had IN after $\approx 3$ months storage.

The lack of IN was confirmed through repropagation of storage roots that had IN symptoms. As a vegetatively propagated crop, in the United States, sweetpotato storage roots are bedded to obtain plants, and plants are transplanted to produce the next season's root crop. When storage roots having IN were bedded for plant propagation, root crop harvested subsequently did not exhibit IN symptoms following full growth and harvest. This was confirmed through controlled studies on the research station and through reports from growers who commercially

\begin{tabular}{llll}
\hline $\begin{array}{l}\text { Units } \\
\text { To convert U.S. to SI, } \\
\text { multiply by }\end{array}$ & U.S. unit & SI unit & $\begin{array}{l}\text { To convert SI to U.S., } \\
\text { multiply by }\end{array}$ \\
\hline 0.1013 & atmosphere $(\mathrm{s})$ & $\mathrm{MPa}$ & 9.8692 \\
29.5735 & $\mathrm{fl} \mathrm{oz}$ & $\mathrm{mL}$ & 0.0338 \\
0.0970 & $\mathrm{fl} \mathrm{oz} / 1000 \mathrm{ft}$ & $\mathrm{mL} \cdot \mathrm{m}^{-1}$ & 10.3065 \\
0.0731 & $\mathrm{fl} \mathrm{oz} / \mathrm{acre}$ & $\mathrm{L} \cdot \mathrm{ha}^{-1}$ & 13.6840 \\
65,198 & $\mathrm{fl} \mathrm{oz} / \mathrm{lb}$ & $\mu \mathrm{L} \cdot \mathrm{kg}^{-1}$ & $1.5338 \times 10^{-5}$ \\
0.3048 & $\mathrm{ft}$ & $\mathrm{m}$ & 3.2808 \\
9.3540 & gal/acre & $\mathrm{L} \cdot \mathrm{ha}^{-1}$ & 0.1069 \\
2.54 & inch $(\mathrm{es})$ & $\mathrm{cm}$ & 0.3937 \\
25.4 & inch $(\mathrm{es})$ & $\mathrm{mm}$ & 0.0394 \\
1 & $\mathrm{ppm}$ & $\mu \mathrm{L} \cdot \mathrm{L}^{-1}$ & 1 \\
6.8948 & $\mathrm{psi}$ & $\mathrm{kPa}$ & 0.1450 \\
$\left({ }^{\circ} \mathrm{F}-32\right) \div 1.8$ & ${ }^{\circ} \mathrm{F}$ & ${ }^{\circ} \mathrm{C}$ & $\left({ }^{\circ} \mathrm{C} \times 1.8\right)+32$ \\
& & &
\end{tabular}



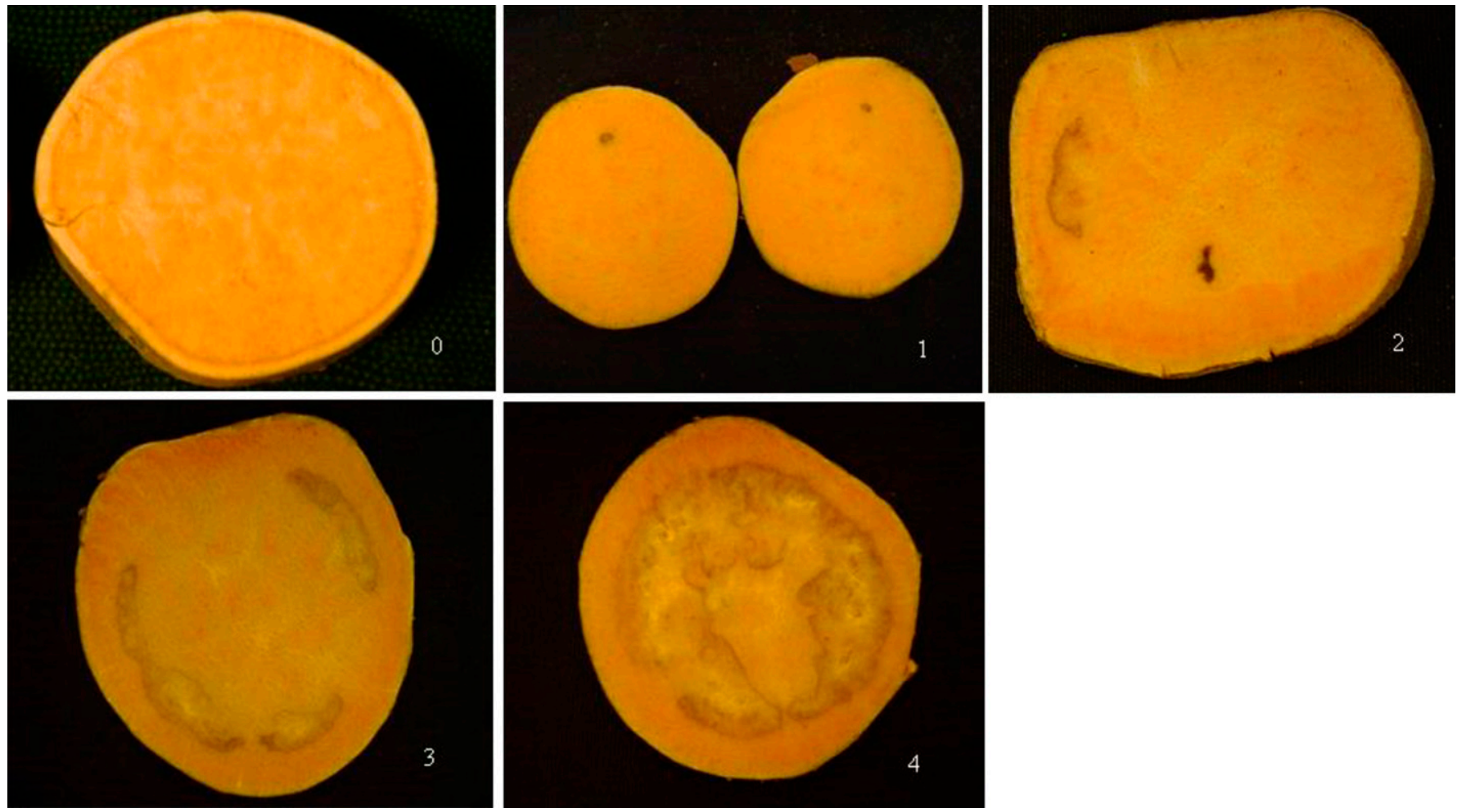

Fig. 1. Sweetpotato internal necrosis (IN) severity rating scale from 0 to $4: 0=$ no symptom, $1=$ negligible but visible symptoms, 2 = obvious symptoms but mainly confined to stem end, 3 = extensive symptoms that either go deeper into the root or have multiple and larger diffuse areas of the root affected and could render roots unmarketable, $4=$ extreme symptoms that go at least one-third of the way into the root from the stem end and render the root unmarketable.

bedded storage roots with IN symptoms (Schultheis and Thornton, 2007). The presence of pathogens was tested on storage roots with IN symptoms. Small pieces of affected tissue were placed in petri plates with acidified po- $^{-}$ tato dextrose agar and incubated at room temperature. No pathogens were consistently isolated other than occasional secondary infections (Schultheis et al., 2009), suggesting a stress-induced physiological disorder.

Previous research indicated that cultivars differ in degree and severity of incidence (Clark et al., 2013; Dittmar et al., 2010). Both preharvest and postharvest factors may affect or initiate IN. Previous work has provided evidence that ethephon might be a causal factor of IN. Ethephon is a compound that releases ethylene gas, which may accelerate the development of the symptom. Several ethephon-based products are available; they contain ethephon as the active ingredient at concentrations of $22 \%$ to $55 \%$, which are designed for different agricultural commodities.

Sweetpotato is sensitive to ethylene in storage (Buescher et al., 1975;
Kitinoja, 1987). Buescher et al. (1975) found that sweetpotato exposed to $10 \mathrm{ppm}$ ethylene during or after curing had enhanced levels of respiration and polyphenol oxidase activities and loss of color and flavor after baking. However, the symptoms of IN were not similar to those seen with ethylene damage (R.W. Buescher, personal communication). Storage roots cured or stored with $1-2 \mathrm{ppm}$ ethylene had increased respiration rate compared with roots cured or stored in ambient air conditions with negligible ethylene (Kitinoja, 1987). Elevated respiration differed among cultivars, from low to high in the tested cultivars, Jersey, Garnet, and Jewel. Total phenolic content also differed with ethylene exposure during curing or storing. Sweetpotato storage roots that were freshly or previously air-cured then stored in an ethylene $(0.1 \mathrm{ppm})$ environment for 1 month had a higher total phenolic rating than roots previously cured in the presence of ethylene and held for 1 month with 0.1 to 10 ppm ethylene (Kitinoja, 1987).

The ethephon product Prep $^{\mathrm{TM}}$ (Bayer CropScience, Monheim am
Rhein, Germany) is currently registered and used to enhance defoliation of cotton (Gossypium hirsutum) and tobacco (Nicotiana tabacum) before harvest. Although not labeled for application on sweetpotato, it has been evaluated as a spray application by the sweetpotato industry to reduce storage root damage at harvest by tightening the epidermis (Main et al., 2009; Wang et al., 2013). Initial research with ethephon was conducted on 'Beauregard' sweetpotato storage roots (Schultheis et al., 2000), and more cultivars, including 'Covington', were used in later studies (Dittmar et al., 2010). At $60 \mathrm{~d}$ after harvest, an incidence of $26.5 \%$ of IN was found in 'Covington' storage roots without ethephon application; but ethephon greatly increased incidence $(74 \%)$ in 'Covington' compared with $12 \%$ of incidence in 'Beauregard'.

The sweetpotato disorder hardcore has some characteristics in common with IN. This disorder is chill-induced with more incidence and severity in 92 to 100 ppm ethylene than in ambient air (Timbie and Haard, 1977). Exposing sweetpotato 
storage roots to elevated carbon dioxide $\left[\mathrm{CO}_{2}(5 \%)\right]$ reduced hardcore severity, whereas hyperbaric conditions (1.7 atm) increased the severity compared with $1 \mathrm{~atm}$ ambient air.

Although sweetpotato storage roots normally produce very low levels of ethylene $\left[\approx 0.1 \mu \mathrm{L} \cdot \mathrm{kg}^{-1} \cdot \mathrm{h}^{-1}\right.$ (Cantwell and Suslow, 2013)], internal ethylene production can be increased in response to black rot fungus (Ceratocystis fimbriata) and cut injury (Imaseki et al., 1968a, 1968b). Rapid production of ethylene from sweetpotato storage roots was observed within $6 \mathrm{~h}$ after roots were sliced, as it stimulated cell metabolic activities, particularly peroxidase and polyphenol oxidase, enzymes involved in the phenylpropanoid and chlorogenic acid pathways (Imaseki et al., 1968c). Ethylene is also reported to play a passive role in the incidence of hardcore (Timbie and Haard, 1977). The diffusion of ethylene from internal tissue of the storage root decreases as root size increases. As a result, more incidence of hardcore is seen in bigger roots, which have smaller surface to volume ratio.

Use of the cultivar Covington is the one consistent factor in the appearance of significant IN in sweetpotato. To better understand and identify possible factors associated with IN, there were studies conducted in commercial storage rooms and at research stations on a range of insecticides and timing of ethephon application to sweetpotatoes. These studies addressed the following four objectives: 1) determine the incidence and severity of IN in the commercial sweetpotato industry of North Carolina; 2) investigate preharvest factors that are related to IN; 3 ) investigate postharvest factors that are related to IN; 4) determine when initiation of IN symptoms occur.

\section{Materials and methods A survey of incidence and severity of IN in commercial sweetpotato storage rooms, and the corresponding storage conditions}

Quality of 'Covington' storage roots was examined from commercial facilities for two storage seasons. After 2010 and 2011 harvests, 'Covington' roots were collected from 25 and 23 growers each year, respectively. In most cases, one room was sampled from each grower, except for a few cases where multiple rooms were sampled from the same growers. As a result, a total of 29 and 27 North Carolina commercial storage rooms were sampled each year, respectively. The list of growers surveyed each year remained mainly the same except for minor adjustments, but the storage rooms that were sampled from same growers differed by year. In each room for each year, 'Covington' storage roots were sampled five times during storage, beginning soon after the harvest season in October and November and concluding the following June and July, with $\approx 6$-week intervals between each sampling. Besides a few initial samples that were collected immediately after harvest, the majority of samples were cured. Each sample consisted of one box of 40 U.S. No.1 (diameter > 1-3/4 inches but $<3-1 / 2$ inches) storage roots [U.S. Department of Agriculture (USDA), 2005] that were selected randomly from bin boxes in storage. Root evaluation for IN symptoms is described in a later section of "Evaluation procedure and statistical analysis."

To track the storage conditions of rooms from which storage roots were sampled, and to visually associate IN incidence with temperature and $\mathrm{RH}$ conditions, one sensor (Hobo U12-011; Onset Computer,
Bourne, MA) was placed in each of the 29 and 27 North Carolina commercial rooms in 2010 and 2011 harvests, respectively. The temperature and $\mathrm{RH}$ of those rooms were monitored hourly, from initial root storage in the fall to final sampling date during the spring.

\section{Preharvest studies: Insecticides and ethephon}

InseCtICIDEs. Two insecticide trials were conducted in 2011 on a loamy sand soil at the Cunningham Research Station, Kinston, NC and the Horticultural Crops Research Station, Clinton, NC, to determine if commonly used insecticides or chemicals being considered for registration could cause IN. Table 1 lists the chemicals being used and their application codes. Plot design was a randomized complete block with four replications. Plots were four rows wide by $40 \mathrm{ft}$ long with $15-\mathrm{ft}$ alleys between each treatment block. Preplant broadcast treatments were applied the day before planting using a powered tractor-mounted sprayer with two 80-02 nozzles (DG 8002; Teejet ${ }^{\circledR}$ Technologies, Wheaton, IL) per row delivering $15 \mathrm{gal} / \mathrm{acre}$ at $40 \mathrm{psi}$. Atplant in-furrow applications were made with a $\mathrm{CO}_{2}$-powered backpack sprayer with a single $80-02$ nozzle in the open row applying $10 \mathrm{gal} / \mathrm{acre}$. At-plant soil drenches were applied by hand pouring $3 \mathrm{fl} \mathrm{oz}$ finished solution

Table 1. Insecticides tested for association with internal necrosis (IN) in 'Covington' sweetpotato at Cunningham Research Station, Kinston, NC and Horticultural Crops Research Station, Clinton, NC in 2011.

\begin{tabular}{|c|c|c|c|}
\hline Location & Treatment & Concn $^{\mathrm{z}}$ & $\begin{array}{c}\text { Application } \\
\text { code }^{\mathrm{y}}\end{array}$ \\
\hline \multirow[t]{9}{*}{ Kinston } & Chlorpyrifos & $0.5 \mathrm{gal} / \mathrm{acre}$ & A \\
\hline & Bifenthrin & $19.2 \mathrm{fl} \mathrm{oz} /$ acre & A \\
\hline & Ethoprop & $6.9 \mathrm{fl} \mathrm{oz} / 1000 \mathrm{ft}$ & $\mathrm{B}$ \\
\hline & Chlorantraniliprole & $7 \mathrm{fl} \mathrm{oz} /$ acre & $\mathrm{C}$ \\
\hline & Clothianidin & $12 \mathrm{fl} \mathrm{oz} /$ acre & A \\
\hline & Imidacloprid & $10.5 \mathrm{fl} \mathrm{oz} /$ acre & A \\
\hline & Bifenthrin & $19.2 \mathrm{fl} \mathrm{oz} /$ acre & $\mathrm{B}$ \\
\hline & Bifenthrin & $19.2 \mathrm{fl} \mathrm{oz} /$ acre & $\mathrm{D}$ \\
\hline & Nontreated & - & - \\
\hline \multirow[t]{6}{*}{ Clinton } & Chlorpyrifos and Bifenthrin & 64 and $19.2 \mathrm{fl} \mathrm{oz} /$ acre & $\mathrm{A} / \mathrm{D}$ \\
\hline & Ethoprop & $60.8 \mathrm{fl} \mathrm{oz} /$ acre & A \\
\hline & Clothianidin & $12 \mathrm{fl} \mathrm{oz} /$ acre & A \\
\hline & Chlorantraniliprole & $7 \mathrm{fl} \mathrm{oz} /$ acre & A \\
\hline & Imidacloprid & $10.5 \mathrm{fl} \mathrm{oz} /$ acre & A \\
\hline & Nontreated & - & - \\
\hline
\end{tabular}

${ }^{\mathrm{z}} 1 \mathrm{gal} /$ acre $=9.3540 \mathrm{~L} \cdot \mathrm{ha}^{-1} ; \mathrm{l} \mathrm{fl} \mathrm{oz} /$ acre $=0.0731 \mathrm{~L} \cdot \mathrm{ha}^{-1} ; \mathrm{l} \mathrm{fl} \mathrm{oz} / 1000 \mathrm{ft}=0.0970 \mathrm{~mL} \cdot \mathrm{m}^{-1}$.

${ }^{\mathrm{y}} \mathrm{A}=$ preplant broadcast incorporated soil application; $\mathrm{B}=$ at plant in-furrow application; $\mathrm{C}=$ at plant soil drench; $\mathrm{D}=$ postplant broadcast incorporated soil application. 
on each plant. Postplant broadcast treatments were applied 2 weeks after planting using a $\mathrm{CO}_{2}$-powered backpack sprayer with two 80-02 nozzles per row delivering $15 \mathrm{gal} / \mathrm{acre}$ at 40 psi.

'Covington' sweetpotato plants were transplanted 7 June in Kinston, $\mathrm{NC}$ and 9 June in Clinton, NC in 2011. There were two harvest times; one during the growing season, the other at normal harvest season that was at least $100 \mathrm{~d}$ after planting (DAP). Storage roots $(80 \%$ large canners grade, diameter $>1$ inch, but $<1$ $3 / 4$ inches; $20 \%$ U.S. No. 1) (USDA, 2005) were harvested during the growing season and dug by hand 82 and 80 DAP in Kinston, NC and Clinton, NC, respectively. Storage roots were cut and rated for IN symptoms within $2 \mathrm{DAH}$. The remaining storage roots were mechanically harvested 100 and 105 DAP at Kinston, $\mathrm{NC}$ and Clinton, NC, respectively, and randomly separated to form multiple subsamples. Each subsample consisted of 25 U.S. No. 1 storage roots, and those roots were cured for $7 \mathrm{DAH}$ at $29{ }^{\circ} \mathrm{C}$ and $85 \%$ to $90 \% \mathrm{RH}$, then placed in $14^{\circ} \mathrm{C}, 90 \%$ to $95 \%$ RH storage. Subsamples were removed from storage for evaluation at 49 (or 29) DAH, 77 (or 63) DAH, 126 (or 120) DAH and 182 (or 177) DAH for the Kinston (or Clinton) study. Root evaluation for IN symptoms is described in a later section of "Evaluation procedure and statistical analysis."

Ethephon. Two ethephon studies were conducted in 2012 to further determine the association between IN occurrence and ethephon application (Dittmar et al., 2010; Jiang, 2013). Previous studies together with our results from the commercial facilities have indicated that the incidence of IN does not increase significantly after the first month of storage, indicating that initiation of symptoms may begin shortly after harvest or soon after curing. In this study, visual symptoms were evaluated in sweetpotato immediately after ethephon application (15 d before mechanical harvest) until $30 \mathrm{~d}$ after harvest.

Early and late plantings of 'Covington' sweetpotato were established 1 May and 21 May 2012 on loamy sand soil at the Horticultural Crops Research Station, Clinton, NC. Each trial was a randomized complete block design comprised of six 6-row plots.
There were two treatments (ethephon and no ethephon control) and three replications. Ethephon (Prep ${ }^{\mathrm{TM}}$ ) was applied 97 DAP for the first planting and $98 \mathrm{DAP}$ for the second planting, using a $\mathrm{CO}_{2}$-powered backpack sprayer with two 80-03 nozzles (DG 8003, Teejet $^{\circledR}$ Technologies) per row delivering $20 \mathrm{gal} / \mathrm{acre}$ at $20 \mathrm{psi}$. The rate of ethephon was $1.3 \mathrm{lb} /$ acre. No rainfall was recorded on either day within $6 \mathrm{~h}$ after application, which satisfied the rain-free period stated on the product label. Before ethephon application, 30 U.S. No. 1 storage roots for each study were sampled randomly across the entire field and cut immediately and examined for the incidence of IN. After ethephon was applied, 20 U.S. No. 1 storage roots were taken from each plot at multiple evaluation times according to the schedule in Table 2. For the early planting study, storage roots for all sampling times were harvested by hand due to wet soil conditions. For the late planting study, hand harvesting was only done during the first two samplings [ 4 and $9 \mathrm{~d}$ after ethephon application (DAE)] and then the whole field was mechanically harvested at $15 \mathrm{DAE}$. All samples were taken from the center four rows in the field plots to avoid spray drift contamination from nearby plots. Root evaluation for IN symptoms is described in a later section of "Evaluation procedure and statistical analysis.”

\section{Postharvest study: Effect of high concentration of ethylene applied during storage}

A high amount of ethylene was applied during root storage to determine if it would induce IN. 'Covington' storage roots, with $90 \%$ of $U$. S. No. 1 size and $10 \%$ of canner size, were obtained from the 2010 and 2011 sweetpotato fields of research trials at North Carolina State University where the crop was grown, cured and stored using standard cultural practices (Kemble et al., 2012).

Whole storage roots were exposed to 100 ppm ethylene gas in storage for $7 \mathrm{~d}$ and sliced periodically afterward to examine them for the occurrence of IN. A total of 20 storage roots were selected randomly and sliced to confirm the lack of IN before any ethylene treatment was applied. The remaining storage roots were then randomly separated into two groups and put into two airtight metal barrels that were $55-\mathrm{cm}$ wide and $75-\mathrm{cm}$ high. Barrel 1 was injected with 100 ppm ethylene (Ethylene Compressed; MWSC High Purity Gases, Charlotte, NC) and barrel 2 contained only ambient air. Ethylene concentration in both barrels was verified by headspace samples injected onto a gas chromatograph (GC-9A; Shimadzu, Kyoto, Japan). Storage roots were in barrels for $7 \mathrm{~d}$ and then were removed to ambient air storage conditions. 20 storage roots, as 20 replications, were sampled per treatment per sampling time. Storage roots obtained from the 2010 season were treated with ethylene starting 29 Mar. 2011, after the roots had been cured and in storage for $\approx 5$ months. These roots were evaluated for IN after 14 and $49 \mathrm{~d}$ of ethylene treatment. As a replication of the study, storage roots were also harvested from the 2011 season. These roots were treated right after being harvested and cured, starting 11 Nov. 2011, and were evaluated 21,82 , and $123 \mathrm{~d}$ after treatment. Root evaluation for IN symptoms is described in the following section.

Table 2. Sampling times of 'Covington' sweetpotato to screen for symptoms of internal necrosis (IN) from fields treated with ethephon at Horticultural Crops Research Station, Clinton, NC in 2012.

\begin{tabular}{lcccc}
\hline $\begin{array}{l}\text { Sample } \\
\text { no. }\end{array}$ & $\begin{array}{c}\text { Time after } \\
\text { application }(d)\end{array}$ & $\begin{array}{c}\text { Time } \\
\text { cured (d) }\end{array}$ & $\begin{array}{c}\text { Time } \\
\text { stored (d) }\end{array}$ & $\begin{array}{c}\text { Time before (-d) or after }(+d) \\
\text { mechanical harvest }\end{array}$ \\
\hline 1 & 4 & 0 & 0 & -11 \\
2 & 9 & 0 & 0 & -6 \\
3 & 15 & 0 & 0 & 0 \\
4 & 18 & 3 & 0 & +3 \\
5 & 21 & 6 & 0 & +6 \\
6 & 23 & 7 & 1 & +8 \\
7 & 30 & 7 & 8 & +15 \\
8 & 35 & 7 & 13 & +20 \\
9 & 45 & 7 & 23 & +30 \\
\hline
\end{tabular}




\section{Evaluation procedure and statistical analysis}

In all of the experiments above, storage roots were sliced horizontally into $\approx 5$-mm-thick sections from the proximal end to the midpoint of the storage root. The incidence of IN for each sample set $(40$ roots per box from growers or 20-25 roots per sample from field experiments) was recorded as a percentage of IN roots of the total. For all studies in this article, the severity for each individual root $\left(S_{i}\right)$ was rated based on a 0 to 4 scale (Fig. 1). Average severity for the grower surveys and for research studies was calculated in different ways. For the grower study, severity of IN incidence for each grower $\left(S_{\mathrm{g}}\right)$ was calculated as an average of $S_{i}$ from all roots that presented IN symptoms across all five samples, to represent the actual severity of individual roots. For research studies, the severity for each plot $\left(S_{p}\right)$ was calculated as the average of $S_{i}$ from all roots that presented IN symptoms in the plot, but severity for each treatment $\left(S_{t}\right)$ (among multiple replicated plots and over years) was calculated as a leastsquare mean of $S_{p}$ through statistical model. The reported data in this article used $S_{\mathrm{g}}$ for grower survey and $S_{t}$ for field experiments. All statistical analysis was conducted through SAS PROC MIXED (version 9.3; SAS Institute, Cary, NC).

\section{Results}

A SURVEY OF INCIDENCE AND SEVERITY OF IN IN COMMERCIAL SWEETPOTATO STORAGE ROOMS AND THE CORRESPONDING STORAGE CONDITIONS. Information obtained from North Carolina commercial rooms indicates that IN is widespread in 'Covington' sweetpotato, but that incidence varies greatly among storage rooms and years (Fig. 2A and B). From 2010 and 2011 harvests, only 2 out of 29 , and 4 out of 27 storage rooms, respectively, had no IN incidence throughout the entire storage season. In 2010 , the majority ( 21 out of 29) of storage rooms had low incidence $(<10 \%)$, whereas during 2011,12 out of 27 storage rooms reported a high incidence $(>10 \%)$. Despite this, only a few rooms during each storage season had an incidence higher than $30 \%$, and those rooms and growers (PK-1 and PK-2 in 2010, SL-3 in 2011) were not the same each
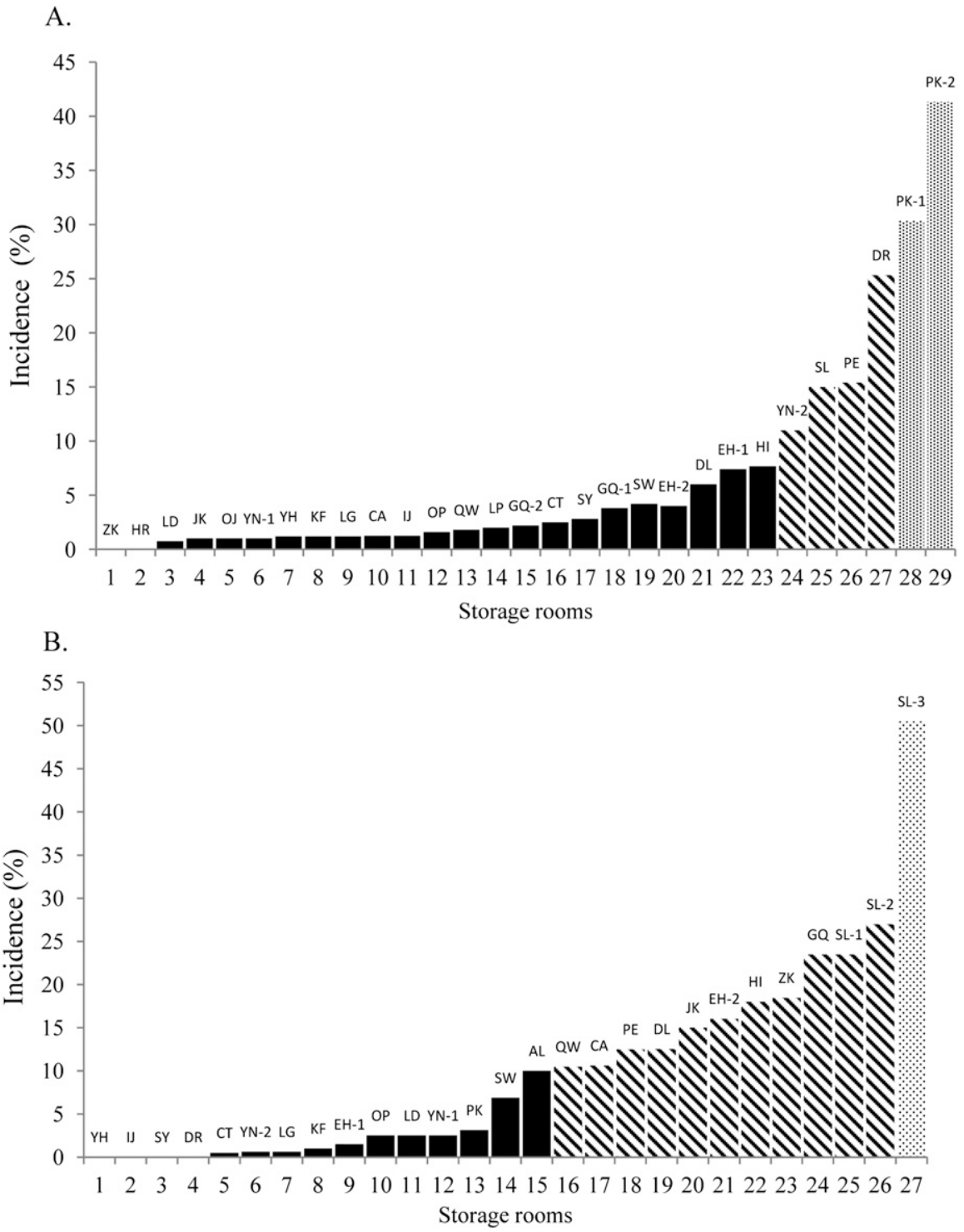

Fig. 2. Average incidence of internal necrosis (IN) in 'Covington' sweetpotato for 29/27 commercial storage rooms in North Carolina for the 2010 (A) and 2011 (B) harvests. Each number indicates a room. Same number on $x$-axis in 2 years does not indicate the same room. A two-letter code (not the initial of the name of grower) is assigned for each grower; for those growers where more than one room was sampled, a number is followed by the grower code (such as XX-1, XX-2). The same grower has the same code in 2 years.

year. It should also be noted that in the room PK-2 which had the highest IN incidence in the 2010 harvest, storage roots that were harvested from different fields, but were cured and stored in the same room, all had IN, although the incidence percentage varied among fields (data not shown).

In both years, most of the roots with IN symptoms were rated as severity 1 or 2 (Fig. 3A and B). Storage roots with these symptoms would generally be considered marketable, as long as incidence is relatively low. In the few rooms each year where symptoms were scored above 2 , the roots were unmarketable, having multiple and large areas of black marbling or necrotic tissue.

When symptom development over time was followed, no trends were seen in either incidence or severity of IN for the five sampling times in each year [data not shown (refer to Jiang, 2013)]. In some storage rooms, the incidence and severity of IN was consistently high throughout the whole storage season. In other rooms, the incidence was high 
in one or two sampling times but not at other times. In most of the rooms, the incidence and severity was consistently low throughout the whole time in storage.

Sensor data on commercial storage conditions showed that in some storage rooms the temperature and $\mathrm{RH}$ were maintained within a very small range around the recommended levels [14 ${ }^{\circ} \mathrm{C}$ and 90\% RH (Kushman, 1975)] [data not shown (refer to Jiang, 2013)]. In other rooms, the temperature and RH greatly deviated from the recommended values over time. A comparison of each room between the condition charts over time and the IN incidence of that room did not show any apparent association between storage temperature/RH conditions and the occurrence of IN. In some storage rooms, the air temperature exceeded $27^{\circ} \mathrm{C}$ for days (especially in early storage period) yet sweetpotato storage roots did not show symptoms of IN. In other rooms, where $\mathrm{RH}$ was below the optimum $(60 \%$ and $70 \%$ throughout the entire time), roots had no or minimal IN incidence. However, in some rooms where optimum
A.

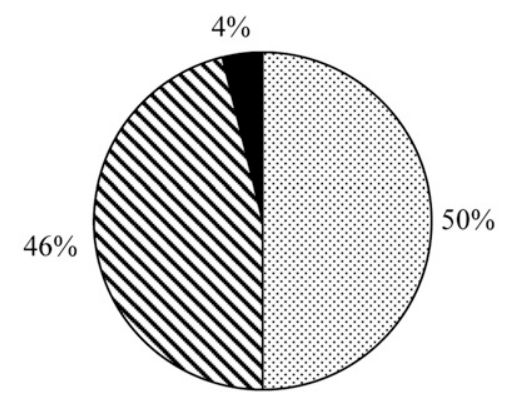

B.

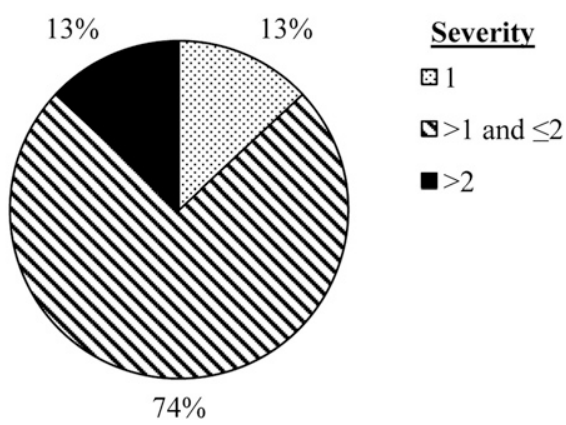

Fig. 3. Severity $\left(S_{g}\right)$ of internal necrosis (IN) in 'Covington' sweetpotato sampled from 29/27 commercial storage rooms in North Carolina for the 2010 (A) and 2011 (B) harvests. Severity of IN for individual root $\left(S_{i}\right)$ was rated based on a 0-4 scale. $S_{g}$, the average severity of each grower was calculated as an average of $S_{i}$ from all roots with IN symptoms from the same grower across all five sample times.

storage temperature and $\mathrm{RH}$ were maintained, a high incidence of IN was sometimes detected.

P REHARVEST ST U D I E S : INSECTICIDES AND ETHEPHON. Internal necrosis was rarely found in storage roots from plots with any of the insecticide treatments in either field location. Only minimal incidence $(<2 \%)$ occurred in the treatments (Table 3) with minor severity, which was not significantly different from the untreated control.

The ethephon study was conducted to determine the effect of ethephon, and the timing for initiation of IN incidence in 'Covington' sweetpotato. A total of 30 storage roots were sampled across the entire field before ethephon application, and cut immediately after harvest. In the early planting, 1 out of 30 roots (severity of 1) was found to have IN; in the late planting, no IN was found in all sampled roots. After ethephon application, sampling time significantly affected the occurrence of IN. Significant main effects, as well as an interaction of ethephon and sampling time, were found (Table 4). Storage roots with the ethephon application had much higher incidence and severity of IN than those from the no-ethephon treatment (Fig. $4 \mathrm{~A}$ and B).

Table 3. Incidence of internal necrosis (IN) in 'Covington' sweetpotato in response to applied insecticides and at different sampling times and locations (Horticultural Crops Research Station, Clinton, NC in 2011 and Cunningham Research Station, Kinston, NC in 2011).

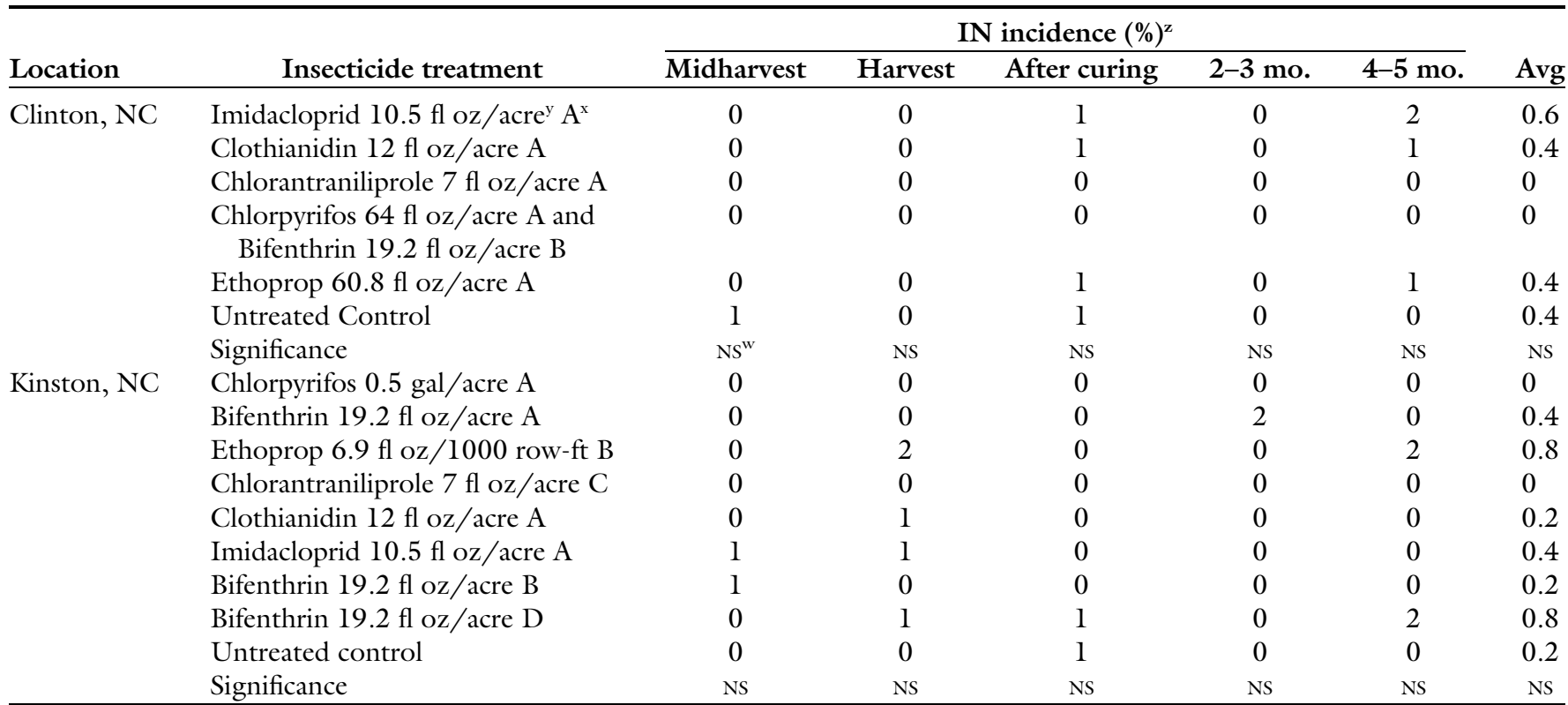

${ }^{\mathrm{z}}$ Incidence of IN was determined by the percentage of incidence in a subsample of 25 sweetpotato storage roots.

y $1 \mathrm{fl} \mathrm{oz} /$ acre $=0.0731 \mathrm{~L} \cdot \mathrm{ha}^{-1} ; \mathrm{l} \mathrm{gal} /$ acre $=9.3540 \mathrm{~L} \cdot \mathrm{ha}^{-1} ; \mathrm{l} \mathrm{fl} \mathrm{oz} / 1000 \mathrm{ft}=0.0970 \mathrm{~mL} \cdot \mathrm{m}^{-1}$.

${ }^{x}$ Capital letters at the end of each treatments indicated the application codes: $\mathrm{A}=$ preplant broadcast incorporated soil application; $\mathrm{B}=\mathrm{at}$ plant in-furrow application; $\mathrm{C}=$ at plant soil drench; $\mathrm{D}=$ postplant broadcast incorporated soil application.

wS means values within the column are not significantly different at $P=0.05$. 
Incidence and severity of IN increased with time in ethephon treated roots, whereas, only severity of IN slowly increased in control treatment roots. Although IN symptoms were observed in sweetpotatoes not treated with ethephon, the incidence and severity was minimal, and did not increase significantly over time. In comparison, minimal presence of IN was found in storage roots from ethephon treated plants until $6 \mathrm{DAH}$, corresponding to the curing period, but both incidence and severity progressively increased until $30 \mathrm{DAH}$.

PosthaRVEST STUdy: EFFeCT OF HIGH CONCENTRATION OF ETHYLENE APPLIED IN STORAGE. Internal necrosis incidence was not significantly affected by sampling date, year, or treatment of high ethylene gas during sweetpotato storage $(100 \mathrm{ppm})$. After treatment application and root storage, only 8 out of 200 sampled storage roots from the 2 years exhibited IN. The small amount of minor symptoms observed from both ethylene-treated and nontreated samples corresponded to the sporadic cases of IN in the commercial storage rooms.

\section{Discussion}

No consistent pattern in samples from commercial storage rooms was associated with the development of IN over time [data not shown (refer to Jiang, 2013)], indicates that induction of symptoms may occur before long-term storage. In 2012, it was observed that roots obtained from different fields and stored in the same room all had high IN symptoms within 1 month of storage, indicating that curing/early storage conditions associated with the room may play an important role in the occurrence of IN (data not shown).

No commonly used insecticides induced IN in our study, but application of ethephon, a harvest aid used for other crops, increased IN in 'Covington' sweetpotato. Similar results were found by Dittmar et al. (2010), and Clark et al. (2013); the authors found that ethephon application was associated with IN development for several sweetpotato cultivars, including Covington, Beauregard, Carolina Ruby, and other clones, and that cultivars differed in IN severity.

In previous studies, small amounts of ethylene ( 1 to $10 \mathrm{ppm}$ ) applied during curing or storage increased storage root respiration rate and the amount of phenolic compounds in the root (Buescher et al., 1975; Kitinoja, 1987). Application of high ethylene concentration (100 ppm) during post-curing storage of sweetpotatoes did not induce IN in our study. Little to no incidence of IN was found after ethephon application at $0 \mathrm{DAH}$ (Fig. 4A and B). The onset of IN was only detected at $6 \mathrm{DAH}$ when roots were still in curing. Foliar ethephon application increases sweetpotato tip rot $(S T R)$ in 'Beauregard'

Table 4. Analysis of variance using SAS PROC MIXED (version 9.3; SAS Institute, Cary, NC) for incidence (A) and severity (B) of internal necrosis (IN) at different sampling times in 'Covington' sweetpotato after preharvest application of ethephon. Severity of IN for individual root $\left(S_{i}\right)$ was rated based on a 0-4 scale. The severity of IN for each field plot (the value used in the statistical model) was calculated as the average of $S_{i}$ from all roots that presented IN symptoms in the plot. The model included Ethephon, Sample_time (Spl_time), and Ethephon by Sample_time (Ethephon x Spl_time) as fixed effects, and Planting, Replication (Planting) as random effects.

\begin{tabular}{|c|c|c|c|c|c|c|c|c|}
\hline \multicolumn{9}{|l|}{ A. } \\
\hline Source & df & $\begin{array}{l}\text { Sum of } \\
\text { squares }\end{array}$ & $\begin{array}{l}\text { Mean } \\
\text { square }\end{array}$ & Expected mean square & Error term & $\begin{array}{c}\text { Error } \\
\text { df }\end{array}$ & F value & $P>F$ \\
\hline Ethephon & 1 & 21.8 & 21.8 & $\begin{array}{l}\text { Var(Residual })+Q(\text { Ethephon, } \\
\text { Ethephon*Spl time })\end{array}$ & MS(Residual) & 85 & 44.32 & $<0.0001$ \\
\hline Spl_time & 8 & 38.1 & 4.8 & $\begin{array}{l}\operatorname{Var}(\text { Residual })+\mathrm{Q}(\text { Spl_time } \\
\text { Ethephon*Spl_time })\end{array}$ & MS(Residual) & 85 & 9.66 & $<0.0001$ \\
\hline Planting & 1 & 0.4 & 0.4 & $\begin{array}{l}\operatorname{Var}(\text { Residual })+ \\
\quad 18 \operatorname{Var}[\operatorname{Rep}(\text { Planting })]+ \\
54 \operatorname{Var}(\text { Planting })\end{array}$ & MS[Rep(Planting)] & 4 & 2.00 & 0.2306 \\
\hline Rep (Planting) & 4 & 0.7 & 0.2 & $\begin{array}{l}\operatorname{Var}(\text { Residual })+ \\
\quad 18 \operatorname{Var}[\operatorname{Rep}(\text { Planting })]\end{array}$ & MS(Residual) & 85 & 0.38 & 0.8239 \\
\hline Residual & 85 & 41.9 & 0.5 & $\operatorname{Var}($ Residual $)$ & . & . & . & . \\
\hline Ethephon & 1 & $8,008.3$ & $8,008.3$ & $\begin{array}{l}\operatorname{Var}(\text { Residual })+Q \text { (Ethephon, } \\
\text { Ethephon*Spl_time) }\end{array}$ & MS(Residual) & 85 & 110.24 & $<0.0001$ \\
\hline Spl_time & 8 & 11500 & 1437.5 & $\begin{array}{l}\text { Var(Residual) + Q (Spl_time } \\
\text { Ethephon*Spl_time })\end{array}$ & MS(Residual) & 85 & 19.79 & $<0.0001$ \\
\hline Ethephon $\times$ Spl_time & 8 & $7,283.3$ & 910.4 & $\begin{array}{l}\operatorname{Var}(\text { Residual })+ \\
\quad \mathrm{Q}(\text { Ethephon*Spl_time })\end{array}$ & MS(Residual) & 85 & 12.53 & $<0.0001$ \\
\hline Planting & 1 & 59.3 & 59.3 & $\begin{array}{l}\operatorname{Var}(\text { Residual })+ \\
18 \operatorname{Var}[\text { Rep }(\text { Planting })]+ \\
54 \operatorname{Var}(\text { Planting })\end{array}$ & MS[Rep(Planting)] & 4 & 0.27 & 0.6284 \\
\hline Rep (Planting) & 4 & 865.7 & 216.5 & $\begin{array}{l}\operatorname{Var}(\text { Residual })+ \\
\quad 18 \text { Var[Rep (Planting)] }\end{array}$ & MS(Residual) & 85 & 2.98 & 0.0236 \\
\hline
\end{tabular}


A.

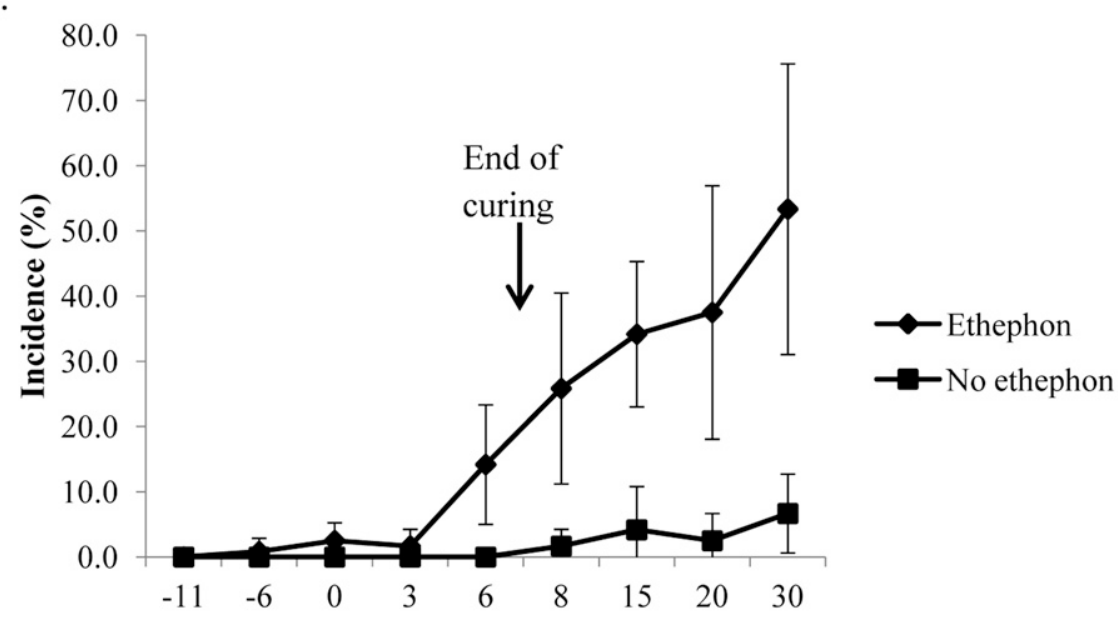

Time after (d) or before (-d) mechanical harvest

B.

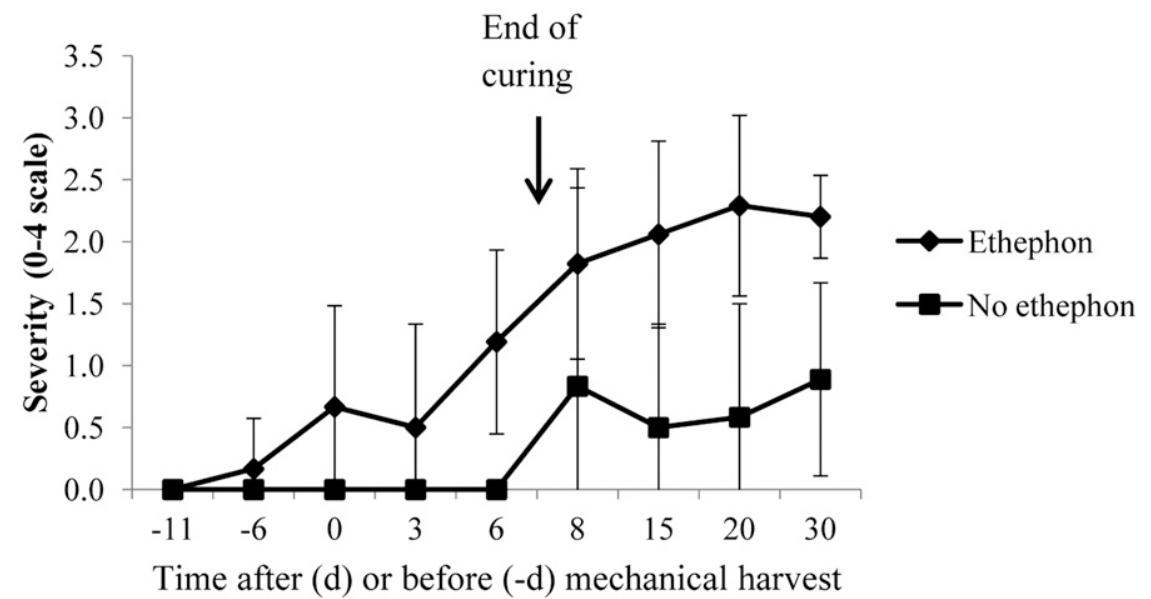

Fig. 4. Effects of ethephon on the incidence (A) and severity (B) of internal necrosis (IN) over time in 'Covington' sweetpotato. Data from two planting times were pooled as there was no significant difference. Severity of IN for individual $\operatorname{root}\left(S_{i}\right)$ was rated based on a 0-4 scale. The severity of IN for each field plot (the value used in the statistical model) was calculated as the average of $S_{i}$ from all roots that presented IN symptoms in the plot. Error bars were expressed as the standard deviation of the mean of each treatment (combination of Ethephon and Sample_time).

storage roots, but symptoms differ from IN (Arancibia et al., 2013). It is suspected that STR is enhanced by ethephon-induced stresses that predispose the root to pathogen infections. In contrast to IN, where incidence is enhanced during curing (Clark et al., 2013), STR was reduced with curing (Arancibia et al., 2013).

In the root crop cassava (Manihot esculenta), an increase in reactive oxygen species (ROS) is one of the earliest steps in postharvest physiological deterioration (PPD) (Zidenga et al., 2012). The ROS increase may be from the hydrolysis process from the cyanogenic alkaloid linamarin to cyanide (Getzin and
Fellman, 2011). This process can occur when storage roots are cut off from the stem and harvested, which may interrupt the respiration in mitochondria and thus lead to PPD. Sweetpotato is harvested in a similar way as cassava, and 'Covington' storage roots separate less easily from vines than the less susceptible cultivar, Beauregard (Dittmar et al., 2010; J.R. Schultheis, unpublished). Programmed cell death may be the underlying nature of sweetpotato IN. In this process, phenolic compounds and ROS increase in response to stress to protect the plant (Beckman, 2000; Gadjev et al., 2008). Future studies on the physiological and biochemical changes of the sweetpotato plant and storage roots at harvest, plus determination of when IN occurs are needed for early detection and to understand the development of this disorder.

In this study, it was found that IN was initiated in storage, suggesting a postharvest issue. However, exposure to preharvest ethephon exacerbated sweetpotato IN. Yet sweetpotatoes from commercial storage facilities that had IN were not treated with ethephon. The conflicting results indicate that there may be multiple causes, or combination of causes, of IN that have not been fully understood, or that there may be pre- or post-curing processes in storage facilities that mimic ethephon.

\section{Conclusion}

These studies demonstrated that $\mathrm{IN}$, a disorder found in sweetpotato storage roots, is widespread among North Carolina commercial facilities in the Covington cultivar, but the overall incidence and severity is relatively low. Temperature, $\mathrm{RH}$, and the existence of high levels of ethylene gas $(100 \mathrm{ppm})$ in storage do not seem to induce symptoms. No currently used insecticides were found to induce IN. Ethephon, a harvest aid (not used commercially on sweetpotato) was found to induce IN and the occurrence was independent of time between application and harvest. Incidence of IN was found as early as $6 \mathrm{DAH}$ and increased up to $30 \mathrm{DAH}$. Future studies are needed to further explore factors such as curing conditions that may contribute to IN in susceptible sweetpotato cultivars.

\section{Literature cited}

Arancibia, R.A., J.L. Main, and C.A. Clark. 2013. Sweetpotato tip rot incidence is increased by preharvest applications of ethephon and reduced by curing. HortTechnology 23:288-293.

Beckman, C.H. 2000. Phenolic-storing cells: Keys to programmed cell death and periderm formation in wilt disease resistance and in general defense responses in plants? Physiol. Mol. Plant Pathol. 57:101-110.

Buescher, R.W., W.A. Sistrunk, and P.L. Brady. 1975. Effects of ethylene on metabolic and quality attributes in sweetpotato roots. J. Food Sci. 40:1018-1020.

Cantwell, M. and T. Suslow. 2013. Sweet potato: Recommendations for maintaining postharvest quality. 29 July 2014. 
$<$ http://postharvest.ucdavis.edu/ pfvegetable/SweetPotato/>.

Clark, C.A., W.L. da Silva, R.A. Arancibia, J.L. Main, J.R. Schultheis, Z.P. vanEsbroeck, C. Jiang, and J. Smith. 2013. Incidence of end rots and internal necrosis in sweetpotato is affected by cultivar, curing, and ethephon defoliation. HortTechnology 23:886-897.

Dittmar, P.J., K.M. Jennings, D.W. Monks, and J.R. Schultheis. 2010. Determining the effect of ethylene on internal black marbling expression in sweetpotato. HortScience 45:488-489 (abstr.).

Gadjev, I., J.M. Stone, and T.S. Gechev. 2008. Programmed cell death in plants: New insights into redox regulation and the role of hydrogen peroxide. Intl. Rev. Cell Mol. Biol. 270:87-144.

Getzin, E. and J.K. Fellman. 2011. Confocal imaging studies of postharvest physiological deterioration in cassava (Manihot esculenta Crantz) root tissue. Acta Hort. 945:113-118.

Imaseki, H., I. Uritani, and M.A. Stahmann. 1968a. Production of ethylene by injured sweet potato root tissue. Plant Cell Physiol. 9:757-768.

Imaseki, H., T. Teranishi, and I. Uritani. 1968 b. Production of ethylene by sweet potato roots infected by black rot fungus. Plant Cell Physiol. 9:769-781.

Imaseki, H., M. Uchiyama, and I. Uritani. 1968c. Effect of ethylene on inductive increase in metabolic activities in sliced sweet potato roots. Agr. Biol. Chem. 32:387-389.

Jiang, C. 2013. Sweetpotato root quality in response to abiotic factors and maximizing greenhouse plant production by adjusting fertilizer application rates. North Carolina State Univ., Raleigh, MS Thesis.

Kemble, J.M., K. Ivors, F.J. Louws, K.M. Jennings, and J.F. Walgenbach. 2012. Sweetpotato, p. 96-97. In: 2012 Southeastern U.S. vegetable handbook. Vance Publ., Lincolnshire, IL.

Kitinoja, L.A. 1987. Effects of low concentrations of ethylene on sweetpotatoes (Ipomoea batatas (L.) Lam) during curing and storage. Acta Hort. 201:37-42.

Kushman, L.J. 1975. Effect of injury and relative humidity during curing on weight and volume loss of sweet potatoes during curing and storage. HortScience 10:275-277.

Main, J.L., M.W. Shankle, and T.F. Garrett. 2009. A comparison of ethephon and conventional vine removal systems for Mississippi sweetpotato. HortScience 44:574 (abstr.).

North Carolina Department of Agriculture and Consumer Service. 2012. Marketing North Carolina sweet potato. 11 Feb. 2015. <http://www.ncagr.gov/ markets/mktnews/swpotsum.pdf $>$.

Schultheis, J.R. and A.C. Thornton. 2007. Determining the expression or lack of expression of internal marbling in Covington roots via vegetative propagation during the growing season and in storage; refinement of nitrogen application rate and timing to optimize yields and root sizing of Covington sweetpotato, $\mathrm{p}$. 69-78. In: North Carolina Sweetpotato Res. Ext. Rpt. 2007. North Carolina State Univ., Raleigh, NC.
Schultheis, J.R., S.M. Blankenship, D.W. Monks, and M.D. Boyette. 2000. Preharvest methods to reduce skinning in 'Beauregard' sweetpotato. HortScience 35:444 (abstr.).

Schultheis, J.R., Z. Pesic-VanEsbroeck, K.M. Jennings, P.J. Dittmar, and A.C. Thornton. 2009. Effects of environmental stress and pathogens on the Internal Mottling and End Rots of sweetpotato in new commercial varieties ('Hatteras' and 'Covington'), and established commercial varieties ('Beauregard' and 'Carolina Ruby'), p. 77-84. In: North Carolina Sweetpotato Res. Ext. Rpt. 2009. North Carolina State Univ., Raleigh, NC.

Timbie, M. and N.F. Haard. 1977. Involvement of ethylene in hardcore syndrome of sweet-potato roots. J. Food Sci. 42:491-493.

U.S. Department of Agriculture. 2005. United States standards for grades of sweetpotatoes. U.S. Dept. Agr., Washington, DC.

Wang, X., R.A. Arancibia, J.L. Main, M. W. Shankle, and D.R. LaBonte. 2013. Preharvest foliar applications of ethephon increase skin lignin/suberin content and resistance to skinning in sweetpotato storage roots. HortScience 48:1270-1274.

Yencho, G.C., K.V. Pecota, J.R. Schultheis, Z. Pesic-Vanesbroeck, G.J. Holmes, B.E. Little, A.C. Thornton, and V. Truong. 2008. 'Covington' sweetpotato. HortScience 43:1911-1914.

Zidenga, T., E. Leyva-Guerrero, $\mathrm{H}$. Moon, D. Siritunga, and R.T. Sayre. 2012. Extending cassava root shelf life via reduction of reactive oxygen species production. Plant Physiol. 159:1396-1407. 